N. Spodyniuk ${ }^{1}$, Cand. Sc. (Tech.), Assoc. Prof., orcid.org/0000-0002-2865-9320,

B. Gulai ${ }^{2}$, Cand. Sc. (Tech.), orcid.org/0000-0001-8031-8171,

V.Zhelykh², Dr. Sc. (Tech.), Prof., orcid.org/0000-0002-5063-5077, S. Shapoval ${ }^{2}$, Cand. Sc. (Tech.), orcid.org/0000-0003-4985-0930

\title{
LEVELING OF PRESSURE FLOW OF RADIAL VENTILATOR IN MINE VENTILATION SYSTEM
}

Purpose. Development of a new structural solution to the element of mine ventilation system to increase its efficiency due to equalization of the flow under different operating modes of radial fans. The task was set to investigate and analyze the effect of the mutual placement of flexible inserts and diffusers and their effect on the overall air flow field, and the energy efficiency of mine ventilation systems as a whole.

Methodology. A design of joining a radial fan to the air supply of a mine ventilation system has been developed. The mathematical processing of results obtained when measuring physical properties is performed on the basis of special programs developed. Theoretical, analytical and experimental methods were used.

Findings. According to results of experimental studies, the quality of the flow in the diffuser and the airline located directly behind the radial fan was estimated. Graphical and empirical dependencies are obtained. It is found that changing the diffuser design allows increasing system performance by $16 \%$. This is important for the further design of the mine ventilation network as it affects improving of the aerodynamic performance of the system. It is established that the most effective equalization of the output stream occurs in the "relatively long" diffuser extension, which is located directly after the fan and in the same diffuser expansion with the flow alignment plate, thereby increasing the flow through the system by $6.7 \%$.

Originality. Quality of the flow in the diffuser and the airline is estimated. It has been established that the most effective leveling of the flow of flux occurs in a diffuser located directly after the fan. The optimal location and the angles of inclination of the alignment plate in the design of the diffuser are determined.

Practical value. The determined optimum locations and plate angles in diffuser expansion design can be used in the design of mine ventilation systems. This will also improve the aerodynamic performance of the mine ventilation system.

Keywords: mine ventilation system, flexible joint, diffuser, flow alignment, expansion angle

Introduction. Continuous increase in prices of energy in a developing economy requires the provision of innovative energy-saving technologies in energy-intensive processes and systems, which include ventilation. Ventilation systems, which are necessary to ensure the operation of process equipment, are an integral part of the mining industry. The cost of the ventilation process can be more than a quarter of the cost of coal. The ratio of produced coal to the outside air consumption is 1 to 30 .

Ventilation in mines should ensure such microclimate in the mine workings, which is necessary for mining. The central mine ventilation scheme, as a type of ventilation system, is used where there is a restriction on the area of the mine field and at low capacity of mines. If the mine is characterized by high power and large amounts of gas, a section diagram of the mine ventilation is used, in which the common mine field is divided into separately ventilated areas.

The main element of the mine ventilation system is a ventilation unit that consists of two fans (working and reserved) with motors.

The radial fans used in the mines are connected to the ductwork through flexible inserts, transitions (diffusers), outlets, as well as straight sections of air ducts the same size as the discharge pipe. The air velocities when leaving the fan housing are usually much higher than the air velocities in the duct behind the fan. In order to reduce aerodynamic losses caused by this phenomenon, the transfer of flow from the fan to the network must be done by successively changing the cross section of the part of the air duct - diffuser. The diffuser accessory to the fan or duct network is rather relative and is relevant in the assessment of a particular mine shaft ventilation system. This question becomes practical only when comparing the fan efficiency using a diffuser and the fan efficiency without using it.

(C) Spodyniuk N., Gulai B., Zhelykh V., Shapoval S., 2019
In air duct systems in a mine ventilation network, diffusers are used very often and their shapes and profiles are quite diverse. By applying diffusers with a design of flexible insert located after the outlet pipe, it is possible to observe a velocity field of considerable irregularity in the air stream as well as the formation of the displacement flow structure, significant turbulence, and large-scale swirls. Such a constructive solution requires additional study and research.

Literature review. Quantity of the uniformity of the velocity field both in the diffuser and the pump opening of the fan depend on the type of fan and modes of its operation [1, 2]. The uniformity of the velocity field and the reduction of pressure losses are possible with the continuous air flow movement in all elements. Therefore, when designing ventilation systems, it is important to use elements with the best geometric dimensions, as well as their most efficient arrangement and taking into account the peculiarities of energy consumption in them.

In the case of large aerodynamic resistance of the mine ventilation network and the extraction of mineral resources with the ability to spontaneous combustion, a combined method of ventilation is used, where one fan works for pumping, and the other - for suction. In this case, the reduction of aerodynamic resistance is possible when using a diffuser of a certain design $[3,4]$

In study [5], a ventilation system was studied where the outlet of air and the opening for air supply were combined into a single module. In comparison to the traditional mine ventilation system, channel lengths have decreased by $68 \%$ and the number of diffusers decreased by $40-50 \%$.

The diffusers are characterized by the following geometric parameters: diffusivity index $\overline{F_{D}}\left(\overline{F_{D}}=F_{\text {out }} / F_{\text {in }}\right)$, relative length $\overline{l_{D}}=l_{D} / b$, opening angle $\alpha$, (where $F_{\text {in }}$ and $F_{\text {out }}$ are the areas of the inlet and outlet sections of the diffuser, $b$ is the characteristic size of the inlet section of the diffuser or the out- 
let opening of the fan). The values of the coefficients of local resistances (coefficients of pressure losses) of the diffusers with different geometric characteristics are indicated in [6, 7]. In study [8], special emphasis is given to parametric modeling of air flows in the fan that allows modifying quickly basic parameters such as the number of blades and the angle of inclination.

Unsolved aspects of the problem. Studies of insulated diffusers have shown that to prevent large losses, the opening angle in them must be small. Otherwise, due to the fact that the velocities in the diffuser are slowed down and the pressure gradient is directed towards the flow, the boundary layer is detached (according to the Bernoulli equation), and large vortex zones are formed near the walls, passing from one wall to another. An increase in the resistance coefficient of the diffuser of a given length with a further increase in the opening angle is caused by large-scale turbulent flow mixing, separation of the boundary layer from the wall of the diffuser and related to these phenomena strong vortex formations $[4,7]$.

In study [9] it is stated that "flat" diffusers are recommended to be constructed with angles $\alpha_{D}<20^{\circ}$, in a symmetric diffuser $\left(\alpha_{2}=\alpha_{1}\right)$, as well as at inclination of one of the walls $\left(\alpha_{2}<\alpha_{1}\right)$. At angles of expansion $\alpha_{D}>20^{\circ}$ it is advisable to use asymmetric diffusers, with the deflection of one of the walls toward the turbine so that the other wall of the asymmetric diffuser is like a continuation of the radial fan casing $\left(\alpha_{2}=0^{\circ}\right)$, or with a deviation $\left(\alpha_{2} \leq-10^{\circ}\right)$. The relative length of the "flat" diffuser $\overline{l_{D}}$ is accepted less than $4-5$ at the opening angle $\alpha_{D}=15-25^{\circ}$.

According to research results, energy losses (pressure) in diffusers, which are connected to radial fans with turbines where blades are bent forward, are indicated in the literature $[9,10]$.

In the study on "flat symmetric" and asymmetric, as well as pyramidal and step-pyramidal diffusers with different angles of inclination of their walls, it was found that in the diffusivity index $\overline{F_{D}}=2-3$ the most optimal are symmetrical diffusers with opening angle $\alpha_{D}=20^{\circ}$ and asymmetric diffusers, where one wall is like an extension of the fan casing, and the other is inclined towards the turbine at an angle of less than $20^{\circ}$. At diffusivity index $\overline{F_{D}}>4$ and with limited diffuser lengths, step-pyramidal diffusers are effectively used [11, 12]. It is advisable to choose the angles and dimensions of their opening with minimal energy losses (pressure), that is, with the minimum value of the coefficient of resistance $\xi_{\min }$ but this greatly increases its length.

Directly in the discharge opening of the radial fan, the air flow that is supplied to the depth of the mine is characterized by increased speeds and it is possible to observe the irregularities of these speeds, significant turbulent flow, small- and large-scale vortex.

In studies $[13,14]$, the distribution of axial velocity fields and excess temperatures and their dependence on the angle of inclination of the alignment plates is shown. At a reduced angle of inclination of the circulating plates, the velocity drop is bigger.

In view of the aforementioned shortcomings, design of new technical solutions for ventilation elements and displacement of diffuser expansion (diffuser) and inserts with flexible, vibrating and insulating material (flexible insert) to ensure their energy efficient operation is a promising and relevant task in improving the energy efficiency of the mine ventilation system as a whole.

Purpose. The main purpose of this work is the physical and mathematical justification, development of new design solutions of the main elements of mine ventilation systems, primarily in order to increase the effective work, due to the balance of the output flow, with different modes of operation of mine centrifugal fans.

In order to achieve this goal, the task was to investigate and analyze the impact of the mutual placement of flexible inserts and diffusers, and their effect on the overall air flow field, and therefore the energy efficiency of mine ventilation systems as a whole.

Methods. The methodology was based on the collection of literature data, analysis of existing diffuser structures for experimental study of the proposed mine ventilation system design. Along with the experiments, control of factors that could cause measurement errors was taken.

The following measurements were made: full and static pressure in the air duct and diffuser, the angle of inclination of the diffuser plate and the length of its recess.

Full and static pressure was measured by the Pitot (Brabbe) tube. The range of total (full) pressures was: $-1650-$ $+2535 \mathrm{~Pa}$

Characteristics of the centrifugal fan VC4-70-4: turbine run $-2860 \mathrm{rpm}$; electric motor with a power of $4.5 \mathrm{~kW}$. Characteristics of V-C4-75-1 fan No. 4: turbine speeds were $1400 \mathrm{rpm}$; electric motor with power $-0.55 \mathrm{~kW}$.

The basis of optimizing research was necessary to follow the constant steps of work:

1) to customize the laboratory installation to a stationary mode of operation;

2) to control the voltage difference in the mains before each experiment.

Results. Experimental studies of the effect of diffuser extensions (diffusers) and flexible inserts interposition, relative to the outlet of the centrifugal mine's fan, were carried out in the laboratory (diagrams of installations are shown in Fig. 1).

Airflow was sucked into the ventilation system from the laboratory room through a centrifugal fan 1 (VC4-70-4 with a turbine speed of $2860 \mathrm{rpm}$ and a motor power of $4.5 \mathrm{~kW}$ ), further flowed through its inlet 2, flowed from the outlet 3 through an insert made with flexible material 5 , to which the diffuser extension 4 was attached (Fig. 1, $a$ ). In another arrangement, the airflow was flowing through the diffuser expansion 4 , to which an insert made with flexible material 5 was attached (Fig. 1,b,d), or flowed through the newly constructed flexible insert 6 and the duct 8 (Fig. 1, c). Forward, the air flow in all cases flowed through a circular air duct 8 (D510 $\mathrm{mm}$ ) and was ejected from the outlet of the ventilation system. When using the Brabbe measuring tube 9 , static and full pressures were determined.

The efficiency of ventilation systems of constant dimensions and configurations was determined by the study of isobars of static and full pressures in different sections of the elements of the output part of the ventilation system, that is in the diffuser extension and the air duct element that was installed instead of the diffuser when using a newly designed flat flexible insert.

Comparison of aerodynamic characteristics of these systems, as well as analysis of isobar full and static pressures provided an opportunity to draw conclusions on the energy efficiency of particular design innovations and solutions, their influence on the structure of air flow in the discharge part of the ventilation system, and according to the operating parameters of the mine ventilation system as a whole.

The distribution of isobars was investigated in sections 1-1 - 6-6 of diffuser expansion in four cases of interposition of ventilation elements (Fig. 2). The pressure measurements were performed at six points of the corresponding sections and were carried out three times for the sake of reliability of the data received. The conditions of the experimental studies were fixed.

The following are full-scale studies of the effects of different placement and new design solutions for ventilation system elements on the flow rate and pressure parameters of mine ventilation systems. The influence of the relative position of the insert with flexible material and the diffuser expansion is shown in Fig. 2, $a, b$. The influence of the use of the latest designs of ventilation elements to align the outlet flow in the radial fan using the latest insert with flexible material as well as 


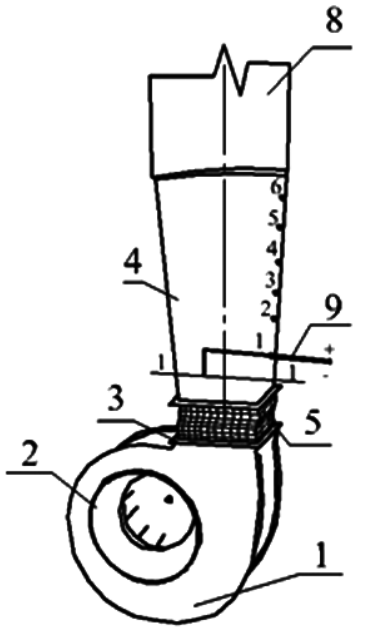

$a$

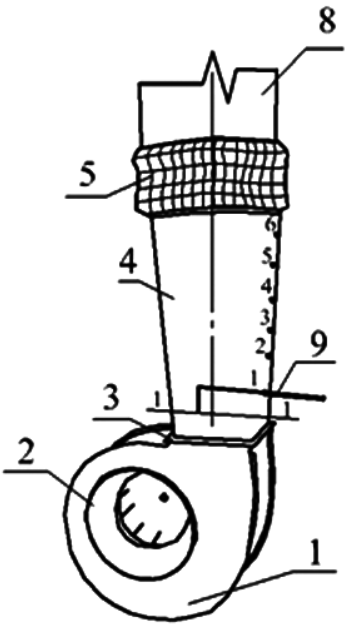

$b$

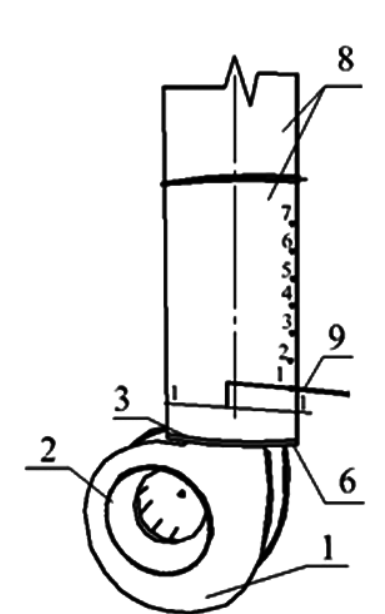

$c$

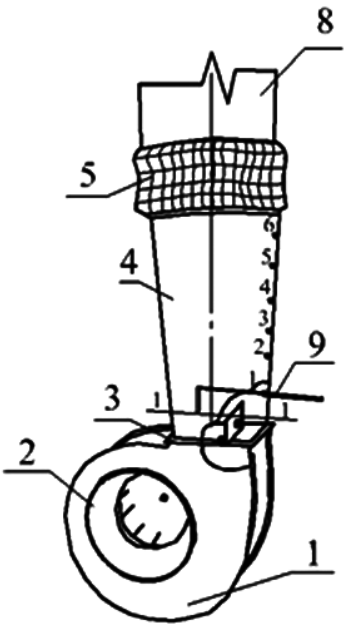

$d$

Fig. 1. Schemes of ventilation systems with a mine centrifugal fan:

$a-$ with an insert made with flexible material, located between the diffuser expansion and the fan; $b$ - with an insert with flexible material, which was located after the diffuser expansion; $c$ - with a new insert with flexible material; $d-a$ system with an insert with flexible material, located after the diffuser expansion and a leveling plate mounted therein; 1 - centrifugal fan (V-C4-70-4); 2-fan inlet; 3 - fan outlet; 4-diffusion expansion; 5 - the usual flexible insert; 6 - designed insert with flexible material; 7 - flow alignment plate; 8-air duct; 9 - (Brabbe) Pitot tube
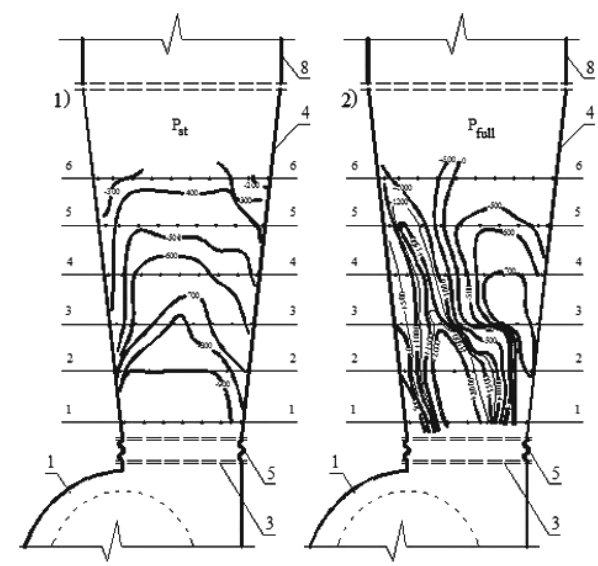

$a$
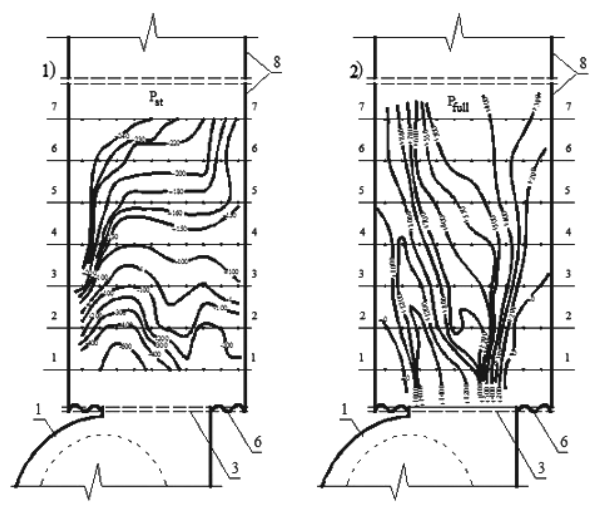

$c$

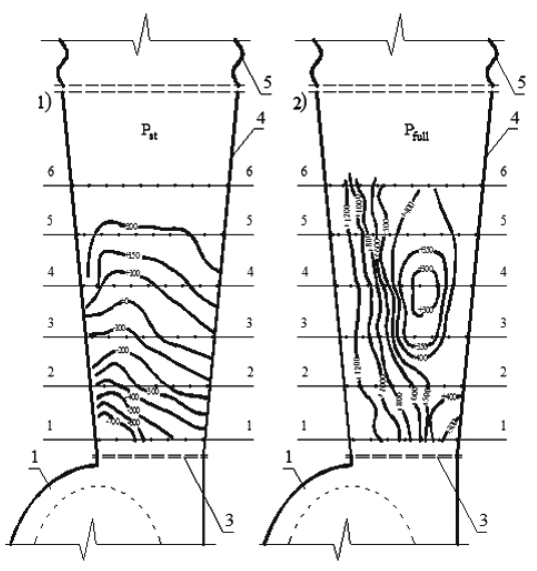

$b$

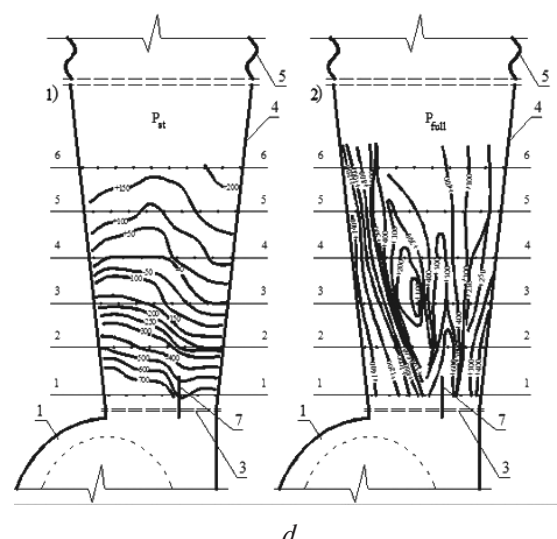

Fig. 2. Experimental studies (1) static and (2) full pressures in mine ventilation systems according to the following schemes:

$a$ - using an insert with flexible material located between the diffuser expansion and the fan; $b$ - using an insert with flexible material located after the diffuser expansion; $c$ - using a new designed insert with flexible material; $d$ - system with an insert with flexible material located after the diffuser expansion and a leveling plate mounted therein

for installation of the plate of flow equalization in the diffuser expansion is shown in Fig. 2, $c, d$.

Studies have shown that it is inefficient to install the insert with flexible material directly after the outlet of the mine centrifugal fan, because negative static pressure zones are formed.
It is shown on the isobar field in the ventilation system in Fig. 1, $a$. Also, this arrangement of elements causes an uneven distribution of full pressures. According to the results of the studies, the full pressure shown in section $1-1$ is variable (the pressure change range is $-1660-+2530 \mathrm{~Pa})$, indicating an un- 
even distribution of dynamic pressures and therefore velocities (Fig. 2,a). The results of the studies showed a large area of negative full pressure, which may be due to the separation of the flow from the diffuser expansion wall on the turbine side. As a result, vortex formations occur. This process causes additional kinetic and full energy loses of air flow, and, therefore, results in a reduction in energy efficiency of the mine ventilation system as a whole.

Analysis of pressure distribution in the ventilation system in case of arrangement of diffuser expansion before an insert with flexible material according to Fig. $1, b$, certified that isobars of negative static pressure are also variable, however, due to the movement of air by diffusive expansion, they change to positive values. In the same case, the isobars of full pressure have positive values in the space of all investigated volume (Fig. 2, b). It was found that the placement of the insert with flexible material downstream (in the case of "relatively long" diffusers $\bar{l}_{D}=3$ with $\alpha_{D}<13^{\circ}$ ) there is an increase in energy efficiency of systems, resulting in relatively better distribution of isobar pressures as well as the flow rate through the system increases by more than $15 \%$, in comparison with the system investigated according to the scheme shown in Fig. 1, $a$.

In experimental studies of mutual influence of the latest structural means for balancing discharge air flow of mine centrifugal fans, it was found that with a sharp change in plane crossing $\left(\bar{l}_{D}=0, \alpha_{D}<180^{\circ}\right)$ from the dimensions $280 \times 280$ of the outlet to the air duct plane with a diameter of $\varnothing 500$ the average velocity in all sections of the duct is increased, as well as the flow rate in total by more than $15 \%$ compared to the inappropriate placement of an insert with flexible material. And the same consequence (the flow rate of system was $6150 \mathrm{~m}^{3} / \mathrm{h}$ ) in the case of placement of "relatively long" diffusers with $\bar{l}_{D}=3$ with $\alpha_{D}<13^{\circ}$. The distribution fields of isobars of dynamic and full pressures according to Fig. 2, $b$ are more uniform compared to the distribution fields of isobars of the same pressures in the system according to Fig. 1, $c$. Analysis of system pressures according to Fig. 2, $d$ found that the volume area of the swirling air flow is smaller compared to the same zone, which was formed in a conventional (typical) diffuser extension according to Fig. $2, b$.

It is found that the most effective balancing of the output flow is observed at "relatively long" diffusers with $\alpha_{D}<13-14^{\circ}$, which are located directly after the fans outlets, as well as when placed in these diffuser extensions of flow alignment plate. Due to this, it was possible to increase the system's performance by more than $7 \%$ compared to the same system, but without the plate. It also increased system performance by $24 \%$ in comparison with the irrational placement of diffuser expansion and insertion with flexible material.

Further experimental studies were conducted to find the most optimal placement of the flow alignment plate in the middle of the diffuser expansion to improve specifications and energy efficiency of the mine ventilation system.

The first stage of the study revealed the optimal lengths of the plate and the value of the recess in the outlet of the mine fan casing by increasing the length of the plate, as well as the optimum placement distance of the flow alignment plate on the opposite side of the fan turbine, taking into account the interaction of these influences.

At the second stage, the most optimal angle(s) of inclination of the same plate was(were) detected for changes in the air performance of this system by periodically changing the value of the fan turbine rotation, and also taking into account the interaction of all these influences.

The studies were performed on the ventilation system according to the scheme shown in Fig. 3. Upon actuation, the centrifugal fan 1 (V-C4-75-1 No. 4 with turbine speed $1410 \mathrm{rpm}$ and power of electric motor $0.56 \mathrm{~kW}$ ) worked for $20-25$ minutes to set the stationary mode of the system totally. The air was sucked into the system by the mine fan 1 and

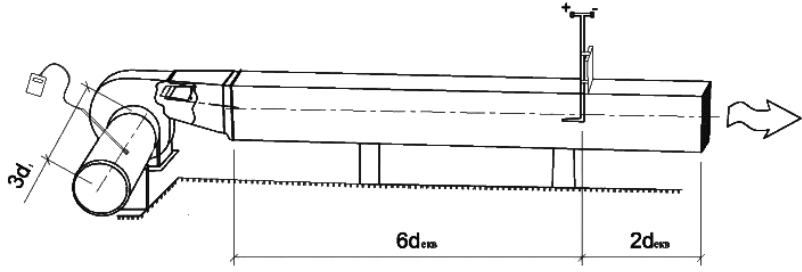

Fig. 3. The layout of the flow alignment plate in the diffuser expansion of the centrifugal fan

flowed through its inlet 2 forced from the outlet 3 into the asymmetrical diffuser extension 4 , with the flow alignment plate 6 located in it. The insert 5 with flexible elastic, tight material, which was a sudden extension and stepwise connected the diffuser 4 to the air duct 7 , was attached to the diffuser.

The diffuser expansion 4 was characterized by such geometrical parameters as the degree of diffusion expansion $\overline{F_{D}}=1.4 \quad\left(\overline{F_{D}}=F_{\text {out }} / F_{\text {in }}\right.$, where $F_{\text {out }}$ and $F_{\text {in }}-$ the cross-sectional areas of the outlet and inlet openings of the diffuser expansion with relative length $\bar{l}=0.7 \quad\left(\bar{l}=l_{D} / D_{\text {equi.in }}\right.$, where $l$ is the length of the diffuser expansion, the angle of expansion of the diffuser $\left(\alpha_{D}=14^{\circ}\right)$, and the equivalent diameter of the input (initial) diameter, respectively $D_{\text {equi.in }}$. The rotational speed of the fan impeller was determined by an electric digital tachometer. The geometric dimensions of the ventilation system were determined by a ruler.

The dimensions of the laboratory where the studies were conducted were sufficient for the required space and volume, where the aerodynamic performance of the ventilation system was measured. The outlet and inlet openings and nozzles were located at sufficient distances from the accessory and the walls of the laboratory. There was no deformation of the suction and discharge jet. To ensure the accuracy and repeatability of the measured indicators, the experiment was repeated twice.

The following factors were taken as input factors.

$\bar{X}_{1}=l_{1} / a-$ the relative value of the distance of the flow alignment plate on the opposite side of the fan impeller, where $l_{1}$ is the distance of placement of the plate on the opposite side of the fan impeller, $\mathrm{mm}$; $\mathrm{a}$ is one of the square openings of the fan outlet, $\mathrm{mm}$.

$\bar{X}_{2}=l_{2} / a$ is the relative amount of dipping of the plate into the outlet of the fan casing by increasing the length of the plate, where $l_{2}$ is the dipping distance of the plate into the outlet, $\mathrm{mm}$.

$\bar{X}_{3}=v / v_{\max }$ is the relative value of the variation of the average speed in the ventilation system on the flow rate, where $v$ is the true average value of the flow velocity of the flow rate in the ventilation system, $\mathrm{m} / \mathrm{s} ; v_{\max }$ is the average value of the flow rate on flow rate with the maximum speed of the fan impeller (according to the technical data sheet of the fan assembly).

$\bar{X}_{4}=\alpha^{\circ}$ is the angle of inclination of the plate in the diffuser asymmetrical extension (the plate was inclined towards the impeller), deg.

Output parameters were selected such as:

$y_{1}=\bar{p}_{f u l l}-$ increase in full pressure in the ventilation system's air duct, \%;

$y_{2}=\bar{Q}_{v}$ - increase in air flow rate through the ventilation system, $\%$.

The results of the increase in pressure and flow rate in the ventilation system due to the location of the plate at a distance $l_{1} / a=0.44$ depending on the relative length of the hollow $l_{2} / a$ for the three modes of operation are presented in Figs. 4, $a, b$.

Using the following functional dependencies it is possible to determine the most optimal placement of the flow alignment plates in the diffuser extension, to maximize the pressure and flow rate characteristics of the ventilation system. 

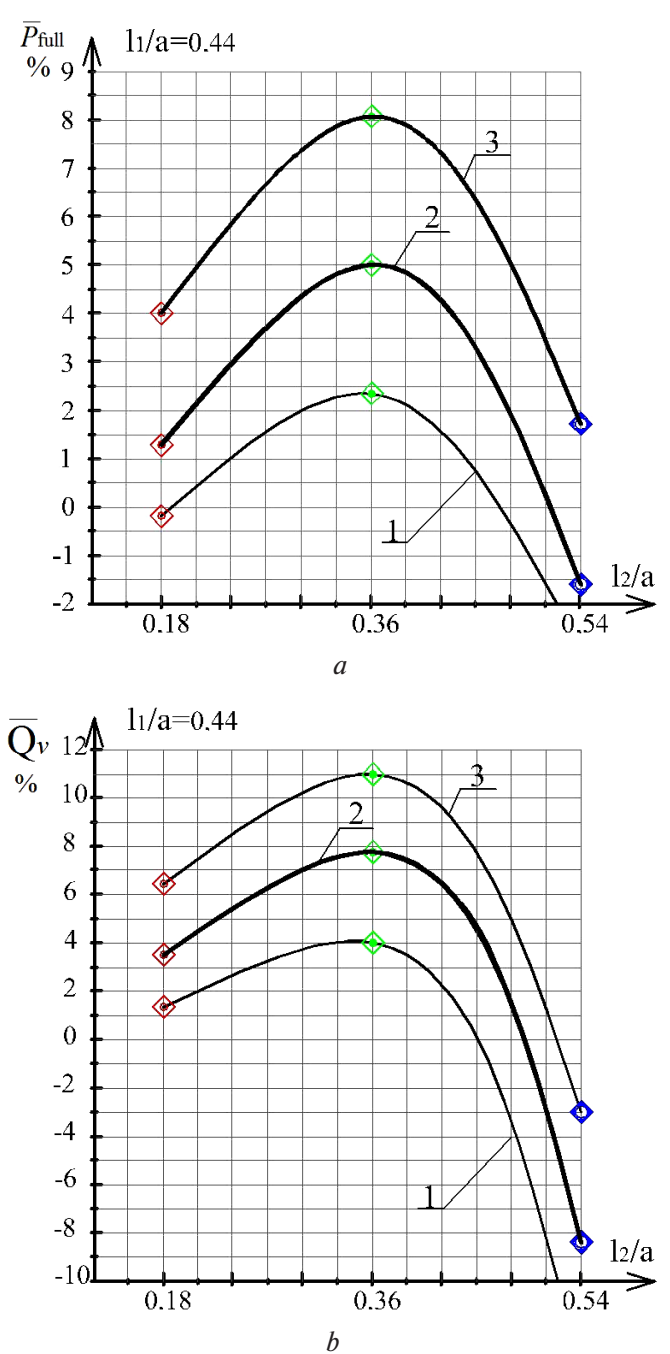

Fig. 4. Two-factor monograms of pressure increase (a) and flow rate (b) in the ventilation system for the plate located at a distance of $l_{1} / a=0.44$, depending on the relative hollow distance of $l_{2} / a$ :

1 - according to nominal mode of operation of the fan; 2 - when operating the fan at maximum efficiency; 3 - when operating the fan at maximum flow rate

$$
\begin{aligned}
& \bar{p}_{\text {full }}=-11.81+7.49 \bar{X}_{1}+89.44 \bar{X}_{2}- \\
& -3.15 \bar{X}_{1}^{2}-16.98 \bar{X}_{1} \bar{X}_{2}-121.74 \bar{X}_{2}^{2} .
\end{aligned}
$$

The maximum value $\bar{p}_{\text {full }}=4.8 \%$ was determined by the Langrange method at $\bar{X}_{1}>0.22$ and $\bar{X}_{2}>0.35$, within $0 \leq \bar{X}_{1} \leq 0.7$ and $0.15 \leq \bar{X}_{2} \leq 0.6$.

$$
\begin{aligned}
& \bar{Q}_{v}=-17.22+16.38 \bar{X}_{1}+130.31 \bar{X}_{2}- \\
& -22.31 \bar{X}_{1}^{2}+11.28 \bar{X}_{1} \bar{X}_{2}-223.47 \bar{X}_{2}^{2} .
\end{aligned}
$$

The maximum value: $\bar{Q}_{v}=3.7 \%$ at $\bar{X}_{1}>0.3$ and $\bar{X}_{2}>0.3$, with in $0 \leq \bar{X}_{1} \leq 0.7$ and $0.15 \leq \bar{X}_{2} \leq 0.6$.

The most optimal relative distance of placement of the flow alignment plate on the side opposite to the fan impeller $\bar{X}_{1}=l_{2} / a=0.26$.

The most optimal hollow of the plate into the outlet nipple of the fan casing by increasing its relative length $\bar{X}_{2}=l_{2} / a=0.3$.

It is also determined that the increase in full pressure in the ventilation system, at different circular speeds of air flow at the outlet of the fan impeller (for different values of its rotational speed) the optimum angles of inclination of the plate in the

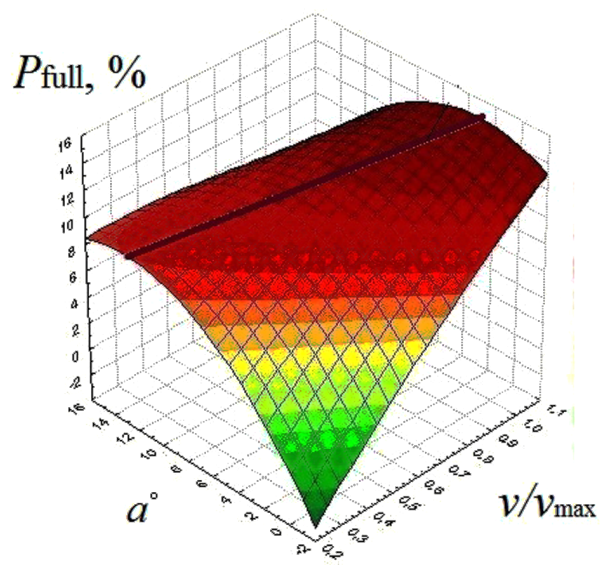

Fig. 5. Dependence of the pressure distribution surface:

$$
\bar{p}_{\text {full }}=f\left(\alpha^{0}, v / v_{\max }\right), \%
$$

diffusion extension are different. This can be clearly observed from the surface dependence of the pressure increase distribution (Fig. 5).

It was determined that the value $\bar{p}_{\text {full }}$ depending on the input factors of the experiment varies in functional dependence (3)

$$
\begin{gathered}
\bar{p}_{\text {full }}=-4.05+21.63 \alpha+1.63 v / v_{\max }- \\
-4.62 \alpha^{2}-1.17 \alpha v / v_{\max }-0.055 v^{2} / v_{\max }^{2} .
\end{gathered}
$$

The composite dependence of the surface of the pressure distribution makes it possible to find the required angles of inclination of the plate (towards fan impeller) to maximize the total pressure in the ventilation system for changes in air performance (by changing the fan rotational speed of the impeller).

According to the results of laboratory studies on the mutual influence and influence of placement of the insert with flexible material and diffuser expansion negative influence was detected of placement of a typical flexible insert connected directly to the outlet of a centrifugal fan on the efficiency of mine ventilation system. It is established that the placement of the insert with flexible material after a "relatively long" diffuser expansion, where $\overline{l_{D}}=2.9$ and at the opening angle $\alpha_{D}=14^{\circ}$, there is an increase in the efficiency of ventilation system, by improving flow rate and pressure characteristics by increasing overall system performance (flow rate through the system) by $16 \%$, compared with the ventilation system shown in Fig. 1, $a$.

Conclusions. The results of the research studies on optimal designs of diffuser extensions of centrifugal fans allow drawing conclusions on the efficiency of their implementation in mine ventilation systems, because only the design of the diffuser can increase the system performance by $16 \%$. This is important in further designing of the mine ventilation network, as it has the effect on improving the aerodynamic characteristics of the system as a whole.

In addition, the quality of the flow in the test ventilation elements was evaluated. It was found that the most effective equalization of the output stream occurs in the "relatively long" diffuser extension, which is located directly after the fan and in the same diffuser expansion with the flow alignment plate, due to which the flow rate through the system increased by $6.7 \%$.

The determined optimum locations and the angles of inclination in the diffuser expansion design can be used in the design of mine ventilation systems. This will also improve the aerodynamic performance of the mine ventilation system.

\section{References.}

1. Xiaodi, H., \& Aimin, J. (2018). Research on Performance Optimization of Multi-Stage Centrifugal Fan. IOP Conf. Se- 
ries: Materials Science and Engineering, 452(042001), (pp. 1-5). https://doi.org/10.1088/1757-899X/452/4/042001.

2. Dadnich, M., Kumar Jain, Sh., Sharma, V., Sharma, S. K., \& Agarwal, D. (2015). Fatigue (fea) and modal analysis of a centrifugal fan. International Journal of Recent advances in Mechanical Engineering (IJMECH), 4(2), 77-91. https://doi. org/10.14810/ijmech.2015.4209.

3. Liang, Y. (2016). Control of coal and gas outbursts in Huainan mines in China: A review. Journal of Rock Mechanics and Geotechnical Engineering, 8(4), 1-9. https://doi. org/10.1016/i.jrmge.2016.01.005.

4. Kopachev, V. F., \& Dolgikh, D. S. (2015). About calculation of aerodynamic characteristics of mine fans of the mixed principle of action. News of the Ural State Mining University, 1(37), 53-55. 5. Park, J.K., Kwon, W.D., Kwon, H.M., \& Yang, J.H. (2017). Examination of the Ventilation Function of a Combined Air-Diffuser Ventilation System Using Experiments and CFD. Journal of Asian Architecture and Building Engineering, 16(3), 647-654. https://doi.org/10.3130/jaabe.16.647.

6. Kapalo, P., \& Spodyniuk, N. (2018). Effect of the variable air volume on energy consumption - case study. IOP Conference Series Materials Science and Engineering 415, (012027) (pp. 1-7). Poland. https://doi.org/10.1088/1757-899X/415/1/012027.

7. Hulai, B., Dovbush, O., Piznak, B., \& Kasynets, M. (2019). Studying Equalization of the Radial Fan's Discharge Flow. Proceedings of CEE 2019, Advances in Resource-saving Technologies and Materials in Civil and Environmental Engineering (pp. 119-126). Lviv, Ukraine. https://doi.org/10.1007/978-3030-27011-7_15.

8. Umamaheswararao, L., \& Ashif, M. (2016). Fluid flow analysis of centrifugal fan by using fem. International Journal of Mechanical Engineering and Technology (IJMET), 7(2), 45-51.

9. Wang, H., Nie, W., Cheng, W., Liu, Q., \& Jin, H. (2018). Effects of air volume ratio parameters on air curtain dust suppression in a rock tunnel's fully-mechanized working face. Advanced Powder Technology, 29(2), 230-244. https://doi. org/10.1016/j.apt.2017.11.007.

10. Liu, H.-H., Cheng, C.-H., Hsueh, K.-L., \& Hong, C.-W. (2017). Modeling and design of air-side manifolds and measurement on an industrial 5-kW hydrogen fuel cell stack. International Journal of Hydrogen Energy, 42(30), 19216-19226. https://doi.org/10.1016/i.ijhydene.2017.06.057.

11. Kapalo, P., Vilčeková, S., Domnita, F., Bacotiu, C., \& Voznyak, O. (2017). Determining the Ventilation Rate inside an Apartment House on the Basis of Measured Carbon Dioxide Concentrations - Case Study. "Environmental Engineering” $10^{\text {th }}$ International Conference Vilnius Gediminas Technical University (pp.1-6). https://doi.org/10.3846/enviro.2017.262. 12. Voznyak, O., Sukholova, I., \& Myroniuk, K. (2015). Research of device for air distribution with swirl and spread air jets at variable mode. Eastern European Journal of Enterprise Technologies, 6(7), 15-23. https://doi.org/10.15587/17294061.2015.56235.

13. Korbut, V., Voznyak, O., Myroniuk, K., Sukholova, I., \& Kapalo, P. (2017). Examining a device for air distribution by the interaction of counter non-coaxial jets under alternating mode. Eastern European Journal of Enterprise Technologies, 2(8), 30-38. https://doi.org/10.15587/1729-4061.2017.96774. 14. Korsun, A.S., Pisarevsky, M.I., Fedoseev, V.N., \& Kreps, M. V. (2017). Velocity distribution in a turbulent flow near a rough wall. Journal of Physics Conference Series, 891(1):012065, 1-10. https://doi.org/10.1088/1742-6596/891/1/012065.

\section{Вирівнювання нагнітального потоку радіального вентилятора у шахтній вентиляційній системі}

\author{
Н.А. Сподинюк', Б. І. Гулай², В. М. Желих ${ }^{2}$, \\ С. П. Шаповал ${ }^{2}$
}

1 - Національний університет біоресурсів і природокористування України, м. Київ, Україна, е-mail: n_spoduniuk@meta.ua

2 - Національний університет „Львівська політехніка“, м. Львів, Україна, e-mail: 08bogdan1986@ukr.net; v_zhelykh@msn.com; shapovalstepan@gmail.com

Мета. Розроблення нового конструкційного рішення елементу шахтної вентиляційної системи для збільшення iii ефективності внаслідок вирівнювання нагнітального потоку за різних режимів роботи радіальних вентиляторів. Сформульована задача дослідити та проаналізувати вплив взаємного розміщення гнучких вставок і дифузорів та їх вплив на загальне поле потоку повітря й на енергоефективність роботи шахтних систем вентиляції в цілому.

Методика. Розроблена конструкція з'єднання відцентрового вентилятора до повітропроводу шахтної вентиляційної системи. Математична обробка результатів, одержаних при вимірюванні фізичних властивостей, виконується за розробленими спеціальними програмами. Використані теоретичні, аналітичні та експериментальні методи.

Результати. За результатами експериментальних досліджень оцінена якість потоку в дифузорі й повітропроводі, розташованих безпосередньо за радіальним вентилятором. Отримані графічні та емпіричні залежності. Встановлено, що зміна конструкції дифузора дозволяе збільшити продуктивність системи на $16 \%$. Це має важливе значення при подальшому проектуванні шахтної вентиляційної мережі, оскільки впливає на покращення аеродинамічних характеристик системи. Встановлено, що найефективніше врівноваження вихідного потоку відбувається у „відносно довгому“ дифузорному розширенні, що розташоване одразу ж після вентилятора, та у цьому ж дифузорному розширенні з пластинкою вирівнювання потоку, за рахунок чого витрата крізь систему збільшилась на 6,7 \%.

Наукова новизна. Оцінена якість потоку в дифузорному розширенні та повітропроводі. Встановлено, шо найефективніше урівноваження нагнітального потоку відбувається у дифузорному розширенні, що розташоване одразу ж за вентилятором. Визначено оптимальне розташування та кути нахилу вирівнювальної пластини в конструкції дифузора.

Практична значимість. Встановлені оптимальні розташування та кути нахилу пластинки в конструкції дифузорного розширення можуть бути використані при проектуванні шахтних вентиляційних систем. Це призведе до покращення аеродинамічних характеристик шахтної вентиляційної системи.

Ключові слова: шахтна вентиляційна система, гнучка вставка, дифузор, вирівнювання потоку, кут розширення

\section{Выравнивание нагнетательного потока радиального вентилятора в шахтной вентиляционной системе}

\author{
Н.А. Сподинюк ${ }^{1}$, Б. И. Гулай², В. М. Желых ${ }^{2}$, \\ С. П. Шаповал ${ }^{2}$
}

1 - Национальный университет биоресурсов и природопользования Украины, г. Киев, Украина, e-mail: ㄴ spoduniuk@meta.ua

2 - Национальный университет „Львовская политехника“, г. Львов, Украина, e-mail: 08bogdan1986@ukr.net; v zhelykh@msn.com; shapovalstepan@gmail.com

Цель. Разработка нового конструкционного решения элемента шахтной вентиляционной системы для увели- 
чения ее эффективности вследствие выравнивания нагнетательного потока при разных режимах работы радиальных вентиляторов. Поставлена задача исследовать и проанализировать влияние взаимного расположения гибких вставок и диффузоров и их влияния на общее поле потока воздуха и на энергоэффективность работы шахтных систем вентиляции в целом.

Методика. Разработана конструкция присоединения радиального вентилятора к воздуховоду шахтной вентиляционной системы. Математическая обработка результатов, полученных при измерении физических свойств, выполняется по разработанным специальным программам. Использованы теоретические, аналитические и экспериментальные методы.

Результаты. По результатам экспериментальных исследований оценено качество потока в диффузоре и воздуховоде, расположенных непосредственно после радиального вентилятора. Получены графические и эмпирические зависимости. Установлено, что изменение конструкции диффузора позволяет увеличить производительность системы на $16 \%$. Это имеет важное значение при дальнейшем проектировании шахтной вентиляционной сети, так как влияет на улучшение аэродинамических характеристик системы. Установлено, что наиболее эффективно уравновешивание выходного потока проис- ходит в „относительно длинном“ диффузорном расширении, которое расположено сразу же после вентилято$\mathrm{pa}$, и в этом же диффузорном расширении с пластинкой выравнивания потока, за счет чего расход через систему увеличился на 6,7 \%.

Научная новизна. Оценено качество потока в диффузоре и воздуховоде. Установлено, что наиболее эффективно выравнивание нагнетательного потока происходит в диффузоре, расположенном непосредственно после вентилятора. Определено оптимальное расположение и углы наклона выравнивающей пластины в конструкции диффузора.

Практическая значимость. Установленные оптимальные расположения и углы наклона пластинки в конструкции диффузорной расширения могут быть использованы при проектировании шахтных вентиляционных систем. Это приведет к улучшению аэродинамических характеристик шахтной вентиляционной системы.

Ключевые слова: шахтная вентиляционная система, гибкая вставка, диффузор, выравнивание потока, угол расширения

Recommended for publication by V.H. Horobets, Doctor of Technical Sciences. The manuscript was submitted 28.02.18. 